Miloš S. Arsić*

student doktorskih studija

Filozofski fakultet

Univerzitet u Beogradu
821.111(73).09-31 Макарти К.

doi 10.18485/analiff.2015.27.2.7

\title{
POREĐENJE KARAKTERIZACIJE LIKOVA U ROMANU NEMA ZEMLJE ZA STARCE KORMAKA MAKARTIJA I FILMSKOJ ADAPTACIJI BRAĆE KOEN
}

Iako karakterizacija nije jedina dodirna tačka između romana Nema zemlje za starce i njegove filmske adaptacije, svakako se radi o jednom od najdominantnijih motiva u opusu njiovih autora koji koriste konkretan žanr kao premisu na kojoj grade sasvim prepoznatljiv stil. U prvom planu ovog rada su analiza okruženja nalik vesternu i mesta koje u njemu imaju tri glavna lika, Levelin Mos, šerif Bel i Anton Čigur, njihov značaj u Makartijevom (McCarthy) romanu i način na koji su prikazani na filmu. Kao ključna sredstva karakterizacije poslužiće poređenje načina na koji su ovi likovi prikazani, njihovo međusobno poređenje i dekonstrukcija vesterna kao premise. Cilj je da se dobije kompletna slika karakterizacije likova, kako na osnovu sličnosti između romana i adaptacije, tako i na osnovu razlika, jer se u i tim razlikama prepoznaje autentičan stil autora. Vestern je tu da bi poručio da ne postoji univerzalan ključ kojim se ovo delo može odgonetnuti. Žanr se razgrađuje jer ne uspeva da prikaže svu složenost života. ${ }^{1}$ Dva sukobljena principa prikazana u romanu i na filmu, sa Mosom uklještenim između njih, ne mogu prestati da se sukobljavaju.

Ključne reči: karakterizacija, vestern, Makarti, Koen, adaptacija

„Pokušavao sam da sklopim mozaik $i$ da stvari smestim na svoja mesta, ali nekad ste toliko blizu svemu tome da vam to ne uspeva. "(Makarti, 2008: 256)

milosars@mts.rs

1 "But we find that notions of the hero, the villain, the narrative and hence the moral framework and the stability of the western film are shattered in the Coen Brothers' No Country for Old Men (2007)... No Country for Old Men demonstrates a decline,or decay, of the traditional western ideal." (Devlin, 2010: 222) 
Kada bi trebalo mimo postojeće literature sažeti smisao jedne adaptacije, onda bi sledio sasvim uopšten zaključak da se radi o postupku kojim se zapleti ili motivi prepričavaju novim sredstvima i u novom medijumu, pri čemu se u onim najboljim i najuspelijim slučajevima prepoznaje sasvim specifičan autorski potpis i originalnog dela, u ovom slučaju književnog predloška, i njegove filmske verzije. U slučaju filma Nema zemlje za starce braća Koen (Coen) su se dosledno držala dva motiva koja se u Makartijevom opusu i inače često javljaju, a to su okruženje nalik vesternu i činjenica da je radnja neretko sasvim podređena likovima. Stoga su poređenje načina na koji su ključni protagonisti romana prikazani u pomenutom romanu i istoimenom filmu i dekonstrukcija vestern okruženja dominantne teme ovog rada. Sa druge strane, cilj nije bio da se dokaže da se kvalitet adaptacije meri po tome koliko je ona verna originalu, već po tome do koje mere se u njoj prepoznaje autentičnost autora, u ovom slučaju braće Koen.

U romanu Nema zemlje za starce Kormaka Makartija i njegovoj filmskoj verziji prepoznajemo elemente više žanrova, ali stiče se utisak da je vestern najdominantniji. I zaista, barem na prvi pogled sve je tu: i prerije zabačenog okruga kakav je Tarel, i glavni negativni junak, i revolveraški obračuni, zli i pohlepni rančeri koji terorišu nevine ljude i šerif koji je tu da ih brani. Pa ipak, radi se o žanrovskoj premisi koja ne samo što se brzo razmontira, već je i vrlo uspešno redefinisana i nadograđena u jednu sasvim novu celinu. Gotovo sve ključne norme i vesterna i drugih žanrova čije elemente prepoznajemo i u karakterizaciji likova ali i van nje su sasvim ozbiljno narušene. Poređenja koja se u tom pogledu nameću ne bi bila kompletna ako se ne obrati pažnja upravo na taj žanrovski kontekst. Vestern će i u ovom radu poslužiti samo kao vrsta orjentira tako da neće biti u prvom planu. Umesto toga, biće objašnjena njegova uloga u karakterizaciji likova. Sažet pregled najosnovnih elemenata ovog žanra je sastavni deo karakterizacije likova i tu je ne samo da bismo shvatili šta glavni junaci jesu, već i što je mnogo važnije - da bi se videlo šta oni nisu.

Ne samo što Mos nije glavni junak, već to nije ni šerif Bel, a Čigur pogotovu nije negativni junak iz popularne kulture ili žanrovske književnosti. Kao rezultat ovakvog postupka u oba slučaja imamo jedno sasvim zaokruženo delo koje po kvalitetu višestruko prevazilazi sve žanrovske odrednice na kojima je zasnovano. I sam roman i njegova filmska adaptacija podjednako su ubedljivi upravo u onim elementima u kojima 
ne poštuju pravila žanra koji im je poslužio kao polazište. U slučaju adaptacije gotovo da potpuno izostaje i muzička podloga, što je još jedan način da se odstupi od klasičnog vesterna u kojem i muzika služi da nagovesti kako se treba osećati tokom neke scene.

\section{Levelin Mos}

„, Kako čovek odluči da napusti svoj dotadašnji život i po kom rasporedu poteza?" (Makarti, 2008: 153)

Jedna od osnovnih premisa klasičnog vesterna jeste da se oko najvažnijih principa morala i pravde sukobljavaju predstavnici dobra i zla. U isto vreme tačno se zna i ko je u drugom planu. Nevini ljudi, u koje bi po toj logici Levelin Mos trebalo da spada, ne mogu sami da se brane; oni stoje po strani i čekaju na rasplet koji je gotovo bez izuzetka u njihovu korist. I osim što su tu da se dive glavnom junaku i da ga u svemu podržavaju, njihov doprinos je sasvim minimalan. Prvi koji se sasvim ozbiljno ne uklapa u jedan ovakav stereotipni obrazac je upravo Levelin Mos. On bi trebalo da je u ulozi pasivnih koliko i nevinih ljudi uklještenih između dva suprotstavljena principa oličena u šerifu i Čiguru. Jer to jesu principi, na tome se dosledno insistira i u romanu i u filmu. U novoj podeli uloga, Mosu jeste dodeljeno središnje mesto. On je između šerifa Bela i nedokučivog Čigura, ali za razliku od klasičnog vesterna, Mos ne čeka konačni obračun ove dvojice. On je taj kojeg bi šerif trebalo da brani i zastupa. Ali Mos niti je pasivan niti je nevin. Temeljna razdgradnja vesterna počinje već od Mosa i tako je sve do samog kraja. A kada na tom kraju Mos pogine, mi ne samo što to i ne vidimo direktno, jer to za priču nije ni bitno, već se time pored ostalog sugeriše i da se ne radi o glavnom liku, bez obzira na to što on ipak nosi radnju maltene u celosti. I to je jedan od načina da se prevaziđe vestern. Kada šerif Bel pred sam kraj romana dolazi u mrtvačnicu da pogleda Levelinov leš, to je prikazano ovako:

„Ličio je na odstreljenog odmetnika.” (Makarti, 2008: 206)

Levelinova smrt ni u filmu nije direktno prikazana. Šerif Bel i dalje ima poštovanja prema Mosu kao što ga ima i prema svim mrtvima. Scena 
u romanu u kojoj šerif sklanja mrtvog sokola sa puta je kao neka vrsta najave Mosove sudbine i nije i jedina ovakva scena. Vrlo brzo postaje jasno da stvari nisu jednostavne kao u klasičnom vesternu. Levelin je sve samo ne nedužan čovek koji se drži po strani. Dok se u romanu on sukobljava sa Čigurom ne zbog neke vrste prestiža, već stoga što blizina novca i sistema vrednosti koji je odabrao neumitno prlibližava i njega i sve koji su mu bliski uništenju koje Čigur predstavlja, u filmu je ovaj sukob prikazan i jednim delom kao neka vrsta rivaliteta i nadmudrivanja, koje u oba ova slučaja ipak počinje zbog novca:

„Ceo njegov život je bio tu pred njim. Dan za danom od zore do mraka dok ne padne mrtav. I sve se to skuvalo i zgusnulo u četrdeset funti papira koji može stati u veću školsku torbu.”(Makarti, 2008: 14)

Način na koji je prikazan sukob Mosa sa Čigurom podseća na čovekovo sukobljavanje sa ništavilom. Mos gotovo da rasipa novac jer mu on nije uvek u prvom planu. Daje ga taksistima, devojci koje slučajno sreće, tinejdžerima od kojih kupuje jaknu:

„Mos uze pet novčanica od po sto dolara i pocepa ih po sredini i onda jednu polovinu preko sedišta pruži vozaču.'(Makarti, 2008: 176) „Iz svežnja izbroja hiljadu dolara i spusti ih na plastični sto i gurnu ka njoj...”(Makarti, 2008: 191)

Ali time kao da im predaje i deo prokletstva koje on sam i taj novac sa sobom nose. Tako skoro svi važniji likovi kojima Levelin daje novac ubrzo poginu, kao u slučaju Karle Džin ili autostoperke. U filmu novac privlači smrt, to jest Čigura slično kao i signalni odašiljač koji se nalazi kod Levelina u torbi.

Jedna od dosledno najvećih razlika između adaptacije i Makartijevog romana je i motiv nove vrste ljudi koji je Makarti pažljivo izgradio, a koji u filmu izostaje. O toj novoj vrsti govore svi i svaki od tri glavna junaka uklapa se u motiv protagoniste novog tipa. Već na samom početku šerif nas podseća na slučaj mladića koji ubija četrnaestogodišnju devojčicu jer je oduvek želeo nekoga da ubije. A takav jedan događaj je u vesternima koje smo svi gledali potpuno nezamisliv. Taj dečak bi u klasičnom vesternu mogao ili da se nađe u senci glavnog junaka i da za njega navija ili da bude 
ubijen i time postane povod za osvetu. Nema zemlje za starce od samog početka narušava taj koncept. Kada Bel pri kraju romana razgovara sa jednim od svedoka saobraćajne nesreće koji je video Čigura, ovaj ne želi da mu kaže kako je Čigur izgledao jer je za to dobio novac. Dakle nisu to više oni dečaci iz vesterna koji obožavaju glavne junake i žele da budu kao oni kad porastu. Naprotiv, stiče se utisak da je šerif Bel jednom bio takav dečak. I Levelin je deo priče o novoj sorti ljudi o kojoj Čigur ovako govori:

„Mogućnost izuzetno velikih profita čini da ljudi preuveličavaju svoje sposobnosti. Ubede sami sebe. Čini im se da kontrolišu događaje što najčešće nije tačno.”(Makarti, 2008: 217)

Levelin Mos iz romana maltene je identičan onome iz filma, ali i dalje je bitno koliko odstupa od klišea koje smo u vesternima navikli da gledamo i tu su braća Koen bila sasvim dosledna originalu. Da pogledamo onda kakav je kontekst u kojem je Levelin prikazan i koji za njegovu karakterizaciju ima najveću vrednost. Kod Makartija se pojedinac ili grupa gotovo po pravilu prikazuju u sukobu sa većim silama prirode ili sudbine koji se odvija van civilizacije, neretko i u pustošima, u ,svoj toj tami i svoj toj hladnoći”. Toga imamo i u njegovom romanu Put i u romanu Krvavi meridijan. U alegoriji koju je Makarti postavio, Levelin je lovac:

„Na stenama je bilo piktograma urezanih pre možda hiljadu godina. Crteži ljudi koji su bili lovci kao i on.’(Makarti, 2008: 8)

Mos zna koja je antilopa koju lovi i to čini malo iz sporta, a malo i zbog potrebe. I to jeste suština tog lika. On je veran svojoj ženi, ali joj ništa ne govori; ne bori se samo za novac, ali ga i ne štedi. Ali kao što zaplet počinje onda kada se vrati na mesto obračuna sa vodom, on je u stvari lovac koji na kraju nalazi sopstveno uništenje jer je pomešao plen i umesto antilope ulovio torbu punu para. I tada neko počinje da lovi njega.

Motiv vode je posebno važan. U slučaju Nema zemlje za starce, roman počinje i završava se vodom. Šerif Bel je predstavljen kao neko ko uvek ima vode, posebno na kraju romana, kada razmišlja o kamenom koritu:

„...Ko zna od kada je tu. Sto...dvesta godina. U kamenu su se videli tragovi dleta. Isklesano je od tvrde stene...da traje deset hiljada 
godina...A to korito za vodu je još tamo. Teško da bi se našao neko ko je u stanju da ga pomeri...” (Makarti, 2008: 267)

Levelinova priča počinje onog trenutka kada, u romanu baš kao i u filmu, odluči da donese vodu nekome ko je ranjen i tako naruši jedan od svojih principa. Manje od sata kasnije i sam je žedan i prinuđen da se bori za goli život.U filmu se posebno insistira na tome da svaki od likova ima neki princip kojeg se pridržava, ali mora da plati kaznu onda kada se tog principa privremeno odrekne: Levelin se vraća po vodu i to plaća životom, Čigur ubija Karlu Džin i odmah doživljava saobraćajnu nesreću. Iako principi glavnih likova čine čest motiv u delima oba autora, principi su ono što Čigura u filmu ipak prikazuje kao čoveka. On je jedini koji svoje principe nije izneverio i u tom, ali i u mnogim drugim pogledima principi su ipak imali nešto jače ili barem drugačije uporište $u$ adaptaciji nego $u$ Makartijevom delu.

U vezi sa dvojicom glavnih likova, Levelinom i Čigurom, uočava se i jedna neobičnost koju su braća Koen očigledno primetila i delimično prenela u svojoj filmskoj adaptaciji. Reč je o simbolizmu vezanom za životinje. Kada Mos u sceni lova na samom početku filma vidi crnog psa koji hramljući odlazi sa scene obračuna, to neodoljivo podseća na Čigura koji hramajući odlazi iz romana u njegovoj poslednjoj sceni. Kada Čigur puca u pticu on je promaši, što može da se shvati kao nagoveštaj da neće on biti taj koji će ubiti Levelina, već neko drugi. Uz Levelinov lik često se pominje jedna uvek ista ptica:

„Nad klisurom se pojavi jastreb.”(Makarti, 2008: 29)

I kao što Čigur ne uspeva da ga ubije, tako ni Bel ne uspeva da ga spase, već samo da ga skloni baš kao što u romanu sklanja jastreba, da ga dodatno ne ,gaze i razmazuju po asfaltu”.

Za razliku od klasičnog vesterna u kojem ne samo što odmah znamo i ko je glavni junak, već ga unapred vidimo kako trijumfuje, kod Mosa postepeno shvatamo da je njegov poraz u obračunima i odmeravanju snaga sa Čigurom kako radnja odmiče sve izvesniji. Autori nisu jedini koji odbacuju norme vesterna koje se od njih očekuju. Odbacuju ih i likovi. Šerif tako ne želi da bude taj koji će braniti pravdu, Čigur ne želi da bude negativni 
junak koji gine na kraju, a Mos ne želi da bude skrajnuti nevini čovek koji pasivno čekati na ishod. I sva trojica u tome uspevaju.

\section{Šerif Bel}

Kao što ni Levelin Mos nije glavni junak, tako ni šerif Ed Tom Bel nije pozitivni junak kakve gledamo u vesternima, čiji moral i principi trijumfuju kada izrešeta negativnog junaka u konačnom obračunu i odjaše u zalazak sunca. Ono u čemu i Makarti i braća Koen prevazilaze i inače ograničene domete vesterna je zapravo ili izostanak ili izvrtanje ključnih obeležja ovog žanra, a finalni sukob dobra i zla to svakako jeste. Alegorija je jedno od najčešćih obeležja Makartijeve proze, tako da postoje sasvim dobri razlozi zbog kojih je ovaj konačni obračun ovako prikazan. Naravno da se ne radi o tipičnom dvoboju iz vesterna gde se sve odvija pred nama, gde se tačno zna ko dobija i gde ništa nije prepušteno slučaju. Umesto toga, Belov poslednji obračun je onaj sa samim sobom, sa vlastitom prošlošću, a ne sa Čigurom. U sukobu sa Čigurom on pre doživljava poraz:

„Dešavalo mu se da se ovako oseća, ali bilo je to davno i kada se toga setio odmah je shvatio šta je to. Poraz. Bio je to osećaj potpune poraženosti. Gorak osećaj."(Makarti, 2008: 266)

Šerif se suočava sa protivnikom protiv kojeg mu veštine i znanja kojima raspolaže ne znače ništa:

„Većina ljudi ne veruje da može da postoji ovakva osoba. Uviđaš kakav im to problem stvara. Kako da prevladaju to čije postojanje odbijaju da prihvate.”(Makarti, 2008: 223)

U starom, tipičnom vestern okruženju šerifovo povlačenje bi se moglo protumačiti kao kukavičluk, ali u ovom novom, kakvo nam nude Makarti i braća Koen, on kao da i nema drugog izbora. U slučaju romana Nema zemlje za starce i njegove filmske verzije, likovi su nosioci principa koji se neprekidno sukobljavaju i taj sukob ni izbliza ne liči na onaj viđen u žanrovima. Taj sukob je kompleksniji od žanra u istoj meri u kojoj su od njega kompleksniji i sami likovi i sve što ih okružuje. Izostanak dvoboja 
ne znači i izostanak pobednika. Pa i tada je taj konačni obračun ili neka vrsta sučeljavanja šerifa i Čigura drugačije prikazana. Radi se o sceni koja je najbliže konačnom obračunu, a to je scena u kojoj se, pri samom kraju, Bel i Čigur nađu zajedno u motelu u El Pasu. Ali adaptacija odbija da pruži bilo kakav konkretan odgovor na to šta se tamo zapravo desilo u istoj meri u kojoj to čini i Makarti. Na neki čudan način, Bel iz ovoga izlazi kao mudriji, kao pobednik i stoga se i povlači. Kao da je njegov trijumf u povlačenju, a ne u sukobu. Ali šerif je istovremeno i jedini koji se ne suočava samo sa Čigurom, već i sa samim sobom i svojim greškama iz prošlosti. Logika koju on prati ne dovodi ga do uništenja oličenog u Čiguru, kao što je to slučaj sa drugim likovima. Kao recimo sa Velsom, na čijem se primeru to jasno vidi kada ga Čigur pita:

„Ako su te pravila kojih si se držao dovela dovde gde si sada, kakav su smisao imala ta pravila?” (Makarti, 2008: 150)

Bel se nije našao u poziciji da mora da odgovori na ovo pitanje. Ali Bel je atipičan lik i po drugim svojim osobinama i njegova ubedljivost ne počiva samo na poricanju vesterna. Šerif se tako javlja i u ulozi pripovedača i u ulozi jednog od glavnih likova. Međutim u tom pripovedanju Bel se drži samo prošlih događaja:

„Jedan od neobičnijih aspekata Belovih monologa je i taj da su oni retrospektivni..."

I Stiven Fraj ističe do koje mere je neobično da kod Makartija lik istovremeno bude i pripovedač i da vidimo tačno šta misli. ${ }^{3}$ Ali Bel nije Makarti. Šerif najviše liči na likove onih dečaka koji u klasičnom vesternu navijaju za glavnog junaka i žele da kada porastu budu kao on. Belovi monolozi sa samog početka dovoljno govore u prilog tome. Kao i u romanu Put, Kormak Makarti u Nema zemlje za starce ponovo pominje motiv čuvara vatre:

2 "One of the odder aspects of Bell's monologue is that it is retrospective..." (King, Volak i dr., 2009: xiv)

3 "For all the comparisons that some have made between McCarhty and Faulkner, in previous works McCarthy has almost universally avoided entering the interior consciousness of character." (Fraj, 2009: 18) 
„,...u trenutku dok je prolazio pored mene video sam da nosi vatru u jednom rogu, kao što se nekad činilo, i rog sam mogao da vidim zahvaljujući svetlosti vatre. Svetlosti boje meseca. I u tom snu znao sam ...da mu je cilj da negde zapali tu vatru u svoj toj tami i svoj toj hladnoći i znao sam da će me kad god ja stignem on tamo čekati.”(Makarti, 2008: 168, 269)

Kao lik koji je tu da brani uspostavljeni sistem vrednosti od onih koji ga narušavaju, Bel se povlači kada shvata da je i taj sistem do te mere promenjen da on više nema šta da štiti, osim onog dela tih vrednosti koji je preživeo u njemu samom, kao ta vatra koju njegov otac nosi u snu. Ali Bel nije jedini razočaran i zbunjen pojavom nove vrste ljudi na kojoj se i u romanu i u filmu toliko insistira. Za razliku od tipičnih heroja Divljeg zapada koji štite nedužne ljude, u slučaju Nema zemlje za starce ovi ljudi nisu više toliko nedužni, već su i samo pomalo iskvareni i otud bliski smrti i Čiguru. Niti je Bel jedini koji je ovime razočaran. Šerif u Igl Pasu ovako komentariše revolveraški obračun:

„Ima dana kad bih od svega digao ruke i pustio da ovakvi preplave sve.” (Makarti, 2008: 115)

I šerif je jedan od likova koji sluti da je došlo do nove podele uloga koju on ne razume, kao što ne shvata gotovo nijednog od likova koji tu ulogu nose:

„Imam osećaj da se susrećemo sa nečim sa čim se do sada nismo suočili." (Makarti, 2008: 39)

„Nikada do tada nisam sreo nekog takvog i počeh da se pitam da li možda nije neka nova vrsta.” (Makarti, 2008: 1)

Šerif je veteran Drugog svetskog rata i njegovo shvatanje sveta ga izdvaja od sasvim novog soja ljudi u koji spadaju i Mos i Vels, obojica veterani rata u Vijetnamu. Šerif se čudi kako Velsovim postupcima s obzirom na karijeru koju je imao. Ali kada na kraju šerif razgovara sa dvojicom dečaka koji su videli Čigura, jedan od njih je ipak spreman da sarađuje. Tako se i među tim dečacima kojima je vestern uzor pravi razlika i time ostavlja bar malo nade. Jedan uzima novac, drugi ne. Vestern u kojem deca bez pogovora navijaju za glavnog junaka više ne postoji. 
Šerif Bel poseduje sasvim određen stav prema smrti i u tom pogledu se njegov lik potpuno razlikuje od Čigura, koji sam predstavlja smrt i uništenje:

„Nikad nikog nisam morao da ubijem i zbog toga mi je veoma drago.” (Makarti, 2008: 53)

Iako se njegove izjave o poštovanju prema mrtvima u adaptaciji tek sporadično prenose, $\mathrm{u}$ romanu se na tome insistira, posebno u sceni sa mrtvim jastrebom koja je u filmu izostala. Bel ne samo što ima poštovanja prema mrtvima, nego zna i da prepozna o kojoj vrsti ptice se radi, kao da time govori kako ume da prepoznaje i tipove ljudi:

„Vozio je skoro 90 na sat ...kad primeti mrtvog jastreba na putu...Podiže ga za jedno krilo i donese ga do jarka pored puta i spusti u travu...Bel nije hteo da ga kamioni gaze i razmazuju po asfaltu." (Makarti, 2008: 37)

Sa druge strane, Čigur je sasvim drugačiji, on puca u pticu koju ne ume ni da prepozna samo da bi proverio da li mu radi prigušivač. Sličnih primera ima još:

„....mrtvi polažu veća prava na nas nego što mi to želimo da priznamo...Imaš osećaj da oni jednostavno ne žele da budu zaboravljeni." (Makarti, 2008: 105)

Mada mu ni u romanu ni na filmu ne pripada bitno mesto, posebno zanimljiv lik je Elis, bivši zamenik Belovog dede, koji se pojavljuje u samo jednoj sceni, gotovo pred sam kraj, kada Bel dolazi kod njega kao što bi dečak iz vesterna otišao kod svog ostarelog idola. Ali Elis je starac u invalidskim je kolicima i sve je samo ne uzor:

„On otvori vrata i uđe u mračnu i hladnu prostoriju...prostorija je mirisala na ustajalu mast i na dim od drva koja su gorela u šporetu, a preko toga se osećao vonj mokraće. Kao vonj od mačaka ali nije bio od mačaka." (Makarti, 2008: 227)

Elis je nepokretan jer je ustreljen. Kada ga Bel pita kako bi reagovao kada bi čoveka koji je to uradio sutradan pustili sa robije, Elis mu odgovara da ne bi preduzeo ništa: 
„Sve vreme koje potrošiš pokušavajući da povratiš ono što ti je oduzeto završava tako da si bacio vreme kroz prozor." (Makarti, 2008: 231)

To da Bel nije Makarti naslućuje se i u sceni razgovora sa Elisom. Bel pita Elisa otkud ovoliko zlo, a Elis mu odgovara da to nije ništa novo i da je toga oduvek bilo. Šerif je taj koji nema kontakta sa istorijom mesta u kojme živi, jer je istorija koja njega zaokuplja u Francuskoj, na ratištu sa kojeg je po sopstvenom mišljenju pobegao.

\section{Anton Čigur}

„, Tamo negde postoji pravi živi prorok uništenja i ja neću da se s njim sretnem." (Makarti, 2008: 2)

Ako već sve liči na vestern a to u stvari nije, onda ni Čigur ne mora nužno da bude ono što izgleda da jeste, a to je smrt, iako smrt nije, barem ne direktno, glavni protagonista u vesternima. Već posle prvog susreta sa Čigurom postaje očigledno da se radi o negativnom junaku, ali još uvek ne i o kakvoj vrsti: nakon što brutalno ubija Lamarovog zamenika Haskinsa, Čigur ulazi u policijski auto i da bi došao do novih kola, on zaustavlja i ubija Bila Virika. Iako pred sobom ima nekoga ko ni izbliza ne liči na policajca, Virik uredno radi sve što mu se kaže u onih poslednjih nekoliko trenutaka života koji su mu ostali. U romanu on čak Čigura oslovljava sa „šerife.” Čigur ga ubija kao što se ubijaju životinje i tako pokazuje Viriku da je i sam deo nove sorte. Tako se sasvim direktno stavlja do znanja i šta Čigur nije, odnosno kakva vrsta negativnog junaka on nije. Jedan od boljih prikaza Čigura ponudio je Rik Volak u svom predgovoru za zbornik radova na temu Nema zemlje za starce, u kojem i sam ukazuje na ono što Čigur nije. Dakle to nije lik plaćenog ubice iz popularne književnosti koji grabi pažnju milionskim ugovorima za ubistva i najsavremenijim naoružanjem sa infracrvenim zracima, hladan kao led koji uvek stigne svoje žrtve, ali tek nakon jurnjave kolima i pucnjave, niti ga igra Brus Vilis (King, Volak i dr., 2009: xv). U slučaju ovog lika javlja se zapravo i najveća razlika u karakterizaciji između romana i filma te je stoga treba detaljnije objasniti.

U romanu je Čigur prorok uništenja, vesnik sudbine ili personifikacija same smrti - zastrašujuće je efikasan. Posle obračuna bandi Meksikanaca u Igl Pasu u koji je slučajno upao svi poginu osim njega: 
„Izašao je na ulicu i pobio sve Meksikance i onda se vratio u hotel. Kao kad bi neko drugi otišao po parče papira ili neku sitnicu." (Makarti, 2008: 130)

Misteriozni biznismen iz Hjustona ga ovako naziva:

„Nepobedivi gospodin Čigur.” (Makarti, 2008: 121)

Kada opisuje kako je ubio čoveka, Čigur i sam sebi daje to svojstvo nestvarnosti:

„,...i ja sam ga onda ubio tu na parkingu i ušao u kola. Svi su se bili skupili oko njega. Nisu shvatali šta se dogodilo. Nisu shvatali da je mrtav. Jedan od njih reče da sam ga uspavao sprejem a ostali se složiše." (Makarti, 2008: 150)

Baš kao prava smrt, on ubija, niko ne zna kako...Ni Vels ga ne opisuje znatno drugačije:

„Nije osoba koju bi voleo da upoznaš. Osobe koje ga sretnu imaju pred sobom skraćenu budućnost. Zapravo i nemaju budućnost."

„Koliko je opasan? Vels sleže ramenima. U poređenju s čim? Sa kugom? Dovoljno je gadan kad ste mene pozvali. On je psihopatski ubica, pa šta? Toliko je takvih koji šetaju na sve strane.” (Makarti, 2008: 121)

Čigur ne reaguje na bol, kao kad odlazi sa mesta saobraćajne nesreće: „...koja su ga tresnula takvom žestinom da su mu slomila ruku na dva mesta i polomila nekoliko rebara i nanela posekotine po glavi i nozi." (Makarti, 2008: 224)

„Jedna kost na ruci mu je virila kroz kožu i on na to uopšte nije obraćao pažnju.” (Makarti, 2008: 252)

I zaista, u sceni u kojoj Mos prelazi granicu sa Meksikom očigledno je da ga rane koje je zadobio sve više bole, ali kod Čigura nije tako. On je metodičan kada sebe leči i čisti svoje rane isto kao i kad radi bilo koju drugu stvar. Nigde uzdah bola, nigde grimasa, ništa:

„Sem malo znoja na čelu, kod njega se nije mogao primetiti nikakav drugi trag napora." (Makarti, 2008: 141, 142) 
Hladnoća mu ne smeta, saobraćajna nesreća mu ne može ništa, Mos ga zarobljava ali ga ne ubija jer se smrt ne ubija:

„Cela soba je polako pulsirala. U vazduhu se osećao neki čudan miris. Kao neka strana kolonjska voda. Pomalo pa kao miris nekog leka." (Makarti, 2008: 96)

„Čovek ga ni ne pogleda. Odavao je utisak kao da ga se sve ovo ne dotiče. Kao da je sve ovo deo njegove svakodnevne rutine." (Makarti, 2008: 96)

Kada predaje torbu sa novcem, Čigur svom budućem poslodavcu kaže doslovce sledeće:

„Siguran sam jer ja rukovodim time ko dolazi i ko ne dolazi." (Makarti, 2008: 216)

I Džon Kant je u svojoj analizi Čigura primetio da najupadljivije osobine ovog lika ne ostavljaju puno nedoumica u pogledu toga šta on predstavlja:

„Iako Makarti daje Čiguru ljudsko obličje, on mu uskraćuje samu ljudskost. Čigurovi postupci i izjave čine ga apsolutno jasnim; on je personifikacija same smrti."4

Priroda ovog lika prepoznaje se i po interakciji sa drugim likovima. Pogledajmo stoga ko mora da ga nađe, ko ga sreće slučajno, a ko po logici svojih postupaka na kraju dovede samog sebe do uništenja koje ovaj lik predstavlja. Bel mora da ga traži. Njegovi postupci nisu kao Mosovi da bi smrt našla njega, već mora biti obrnuto. Sa druge strane, svojim postupcima i Mos i Vels nalaze uništenje. Uništenju i smrti posebno su bliski oni likovi koji su motivisani novcem i oko njega se obračunavaju. Novac je ili večito umrljan krvlju onih koji su se oko njega otimali ili je obeležen odašiljačima koji do njega vode i kojima ga neko uvek traži, bez prestanka. Neke od njih do Čigura logično dovodi put koji su za sebe odabrali. Tako šerif komentariše smrt meksičkih dilera droge:

$4 \quad$ "Although McCarthy gives Chigurh human form, he denies him human qualities. Chigurh's actions and words make his meaning abundantly clear; he is death personified." (Kant, 2008: 249) 
„Verujem da je ovaj umro od prirodnih uzroka.

Od prirodnih uzroka?

Tako je. U skladu sa poslom kojim se bavio.” (Makarti, 2008: 65)

I upravo u skladu sa tim poslom javlja se i motiv novčića koji Čigur baca da odluči nečiju sudbinu. Jer on to čini samo kada su u pitanju nevini ljudi, koji mu nisu direktni protivnici. Postoje dva takva slučaja, jer postoje i dva moguća ishoda. Karla Džin nije imala sreće, prodavac na benzinskoj pumpi jeste.

Naravno da je i u filmu ovaj lik prikazan na sličan način, ali ipak postoje razlike. U filmu se pre stiče utisak da niko ne može da pobegne sudbini i da su svi smrtni. Ne insistira se na alegoriji. Tako i scena saobraćajne nesreće u filmu ima sasvim drugačije značenje. Čigur je bliži tome da bude ljudsko biće, ali ni tu on nije bilo koje ljudsko biće. U sceni kada samom sebi čisti ranu, Čigur očigledno pokazuje bol. Onda, kada doživi saobraćajnu nesreću, to pre liči na čoveka koji, iako sistematičan, i dalje ne može da pobegne sudbini. Koliko god da je temeljan, on je ipak samo ubica i zato je i skrajnut. Odlazi gotovo neupadljivo, isto kao i onaj crni pas na početku filma, skoro kao i Levelin Mos. Ovde se radi o jednom motivu koji su braća Koen već koristila. U jednoj sceni pred sam kraj njihovog filma Tihi čovek, glavni junak dobija fatalne nalaze lekarskog pregleda s početka filma upravo u trenutku kada, na samom kraju, prekrši sopstveno pravilo. Tu se posebno prepoznaje autorski potpis braće Koen. Tako i Čigur umalo gine u saobraćanoj nesreći onda kada, poštujući sopstveni princip, mimo svake logike ubija Karlu Džin.

Još jedna od važnijih stavki je Čigurov gotovo karikaturalan izgled koji ovaj lik ima u filmskoj adaptaciji. Sve je na njemu čudno: i gotovo smešna frizura i jeziva puška:

„Puška je imala čudan brektavi zvuk. Kao da neko u cevi kašlje” (Makarti, 2008: 89)

Oni koji se suoče sa njim, moraju da ga gledaju u oči:

„Čigur izvadi pištolj koji mu je bio za pojasom. Pogleda čoveka u oči. Čovek skrenu pogled.

Pogledaj me, reče Čigur. 
Ne sklanjaj pogled. Hoću u mene da gledaš.

On pogleda u Čigura. Pogleda na novi dan koji je na sve bacao svoju svetlost. Čigur ga ustreli kroz čelo i ostade da posmatra. Kako svetlost nestaje. Svoj lik kako nestaje u svetu koji se gasi." (Makarti, 2008: 104)

Za razliku od filma, u romanu je taj izgled predstavljen kranje neodređeno:

„Srednje visine. Srednje građe, ali kao neko ko je u dobroj formi. Između trideset i četrdeset godina. Crna kosa. Ili tamno smeđa, ne znam. Šerife, izgledao je k’o bilo ko.” (Makarti, 2008: 252)

U nekim aspektima međutim, filmska verzija Čigura ima puno zajedničkog sa likom iz romana:

„Čovek prvi put pogleda Čigura u oči. Plave kao lapis. Svetle i tamne istovremeno. Kao vlažno kamenje.” (Makarti, 2008: 47)

„Plave oči. Mirne. Tamna kosa. Nešto egzotično bilo je u njemu. Nešto van Mosovog dotadašnjeg iskustva." (Makarti, 2008: 96)

Nema zemlje za starce nije klasičan vestern i u još jednom pogledu ovde su najamnici ti koji eliminišu svoje nalogodavce, kao što Čigur ubija tajanstvenog biznismena iz Hjustona koji za njega kaže:

„Čigur je odmetnik.” (Makarti, 2008: 136)

I jeste, odmetnik je iz sveta iz kojeg nismo navikli da gledamo odmetnike. Iako smo ovakve preokrete i ranije viđali u vesternima, posebno u špageti vesternima, oni su ipak retkost. U filmu Čigur kao da kažnjava pomenutog biznismena što nije odabrao pravi alat za posao, što samo dodatno govori u prilog činjenici da on nije čovek. Tu je Čigur atipičan negativni junak, jer poseduje u suštini osobinu pozitivnog lika, a to je da je iznad novca ili droge, da je nepotkupljiv.

„On je čudan čovek. Čak bi se moglo reći da poštuje principe. Svoje principe. A na njegove principe nikakav uticaj nemaju ni novac ni droga." (Makarti, 2008: 133) 
„Njemu novac ništa ne znači.” (Makarti, 2008: 129)

Čigur je smrt i onda kada se uporedi sa likom Karsona Velsa, koji bi po logici vesterna trebalo da mu je najsličniji. U romanu Vels nalazi leš starice i kalendar koji proriče dan njegove smrti. Tako Karson Vels postaje još jedan dokaz da je Čigur smrt, jer u trenutku kada po kalendaru koji je našao treba da umre, on sreće upravo Čigura. Evo kako je opisana scena u kojoj Čigur ubija Velsa:

„Sve što je Vels ikada znao ili mislio ili voleo curilo je polako niz zid iza njega. Lice njegove majke, prva pričest, žene koje je poznavao. Lica ljudi koji su pred njim na kolenima umrli." (Makarti, 2008: 153)

Zato Vels i Čigur jesu „stari znanci”, jer Vels očigledno dobro poznaje smrt, a Čigur to jeste. Postavka klasičnog vesterna je u ovom filmu i u romanu zapravo poražena i kroz poraz prototipskih likova za jedan vestern, jer ima i takvih. To su Karson Vels i tajanstveni biznismen iz Hjustona. Kao što u vesternima najčešće biva, interese pohlepnih rančera brane ništa manje zli revolveraši. Karson Vels je u ulozi ovih drugih. On je upravo taj lik negativnog junaka iz popularne književnosti čija je logika tako duboko poražena pre nego što je ubijen. Dovođenjem likova u zajednički kontekst i istu ravan dodatno se naglašava razlika između njih. Na prvi pogled sam kontekst upućuje na prepoznavanje, ali vrlo brzo svaki kontekstualni orjentir postaje nedovoljan. Suština je negde drugde. Likovi zaista dele puno sličnosti na kojima se ne insistira slučajno. Kao što su osobine klasičnih pozitivnih i negativnih junaka izmešane, tako je moderan svet s početka osamdesetih izmešan sa vek i po starijim dobom u kojem se dešava radnja većine vesterna.

Ali Čigur nije samo egzekutor ljudi: on podjednako efikasno briše i njihove principe. Tako ne samo što ubija Velsa, on poništava Velsovu životnu logiku, da ni ona ne bi preživela:

„Odustajao si od mnogo stvari tokom godina da bi najzad dospeo dovde. Ne shvatam to. Kako čovek odluči da napusti svoj dotadašnji život i po kom rasporedu poteza?” (Makarti, 2008: 152)

Vels i nudi novac Čiguru da mu ovaj poštedi život baš zato što ne shvata s kim ima posla, da se smrt ne može potkupiti: 
„I dalje je ono pristojan novac.

Jeste. Ali u pogrešnoj valuti." (Makarti, 2008: 149)

I kod Velsa se javlja motiv gledanja smrti u oči:

„Misliš da očima možeš da odložiš neodložno.

Šta očima?

Misliš da može da se odlaže dokle god me gledaš." (Makarti, 2008: 152)

Sa druge strane, pravila koja je pratio Bel, kao simbol jednog drugačijeg životnog stava, ne dovode ga do uništenja. Šerif postupa sasvim obrnuto: za njega smrt jeste kraj, ali on čuva uspomenu na mrtve, na ćerku koja bi u trenutku kada se radnja dešava imala 30 godina i sa kojom ponekad razgovara. U onoj meri u kojoj Bel pokazuje poštovanje prema mrtvima, Čigur nastavlja da ih poništava i posle njihove smrti, što se vidi u razgovoru sa Karlom Džin, kada mu ona kaže:

„Ne dugujete ništa mrtvima.

Čigur malo iskrivi glavu. Ne? reče on.” (Makarti, 2008: 220)

„On odmahnu glavom. Tražiš od mene da sebe proglasim ranjivim, a to ne mogu da uradim. Imam samo jedan način života. Tu nema mesta za izuzetke. Možda novčić tu i tamo. U ovom slučaju bez rezultata. Većina ljudi ne veruje da može da postoji ovakva osoba. Uviđaš kakav im to problem stvara. Kako da prevladaju to čije postojanje odbijaju da prihvate. Razumeš?” (Makarti, 2008: 223)

Čigur ubija pištoljem na vazdušni pritisak i time svodi svoje žrtve na životinje, a tako ih i ubija. Dehumanizovanje i uopšte gubitak humanosti su čest motiv kod Makartija, kao recimo u romanu Put, gde se pored ubijanja javlja još i kanibalizam. Čigur depersonalizuje svoje žrtve. I on pominje novu vrstu ljudi:

„Od sada ćemo poslovati sa novim ljudima.

Šta je bilo sa starom ekipom?

Sklonili su se, nisu više u ovom poslu. Nije svako podesan za ovu vrstu posla. Mogućnost izuzetno velikih profita čini da ljudi 
preuveličavaju svoje sposobnosti. Ubede sami sebe. Čini im se da kontrolišu događaje što najčešće nije tačno. I tako se privlači pažnja neprijatelja. (Makarti, 2008: 217)

Već na samom početku imamo i nagoveštaje da će ovde sve to biti drugačije, pa i sam kraj. Dobro na kraju ne trijumfuje. Ali ono što bi moglo da opravda šerifa jeste da u klasičnom vesternu do konačnog obračuna dolazi dok je još sve u igri. Ovde nije tako. Čigur je već eliminisao sve bitne likove i pitanje je koga bi i zašto Bel trebalo da brani. Karlu Džin nije spasao jer mu nije palo na pamet da bi Čigur mogao nju da traži i da je ubije. Kraj romana i adaptacije je u tom pogledu posebno zanimljiv. Razgradnja vesterna se pogotovo može prepoznati po tome što ne samo što se ništa ne završava kao u vesternu, već i što bi bilo teško zamisliti klasičan, dobar kraj jednog ovakvog zapleta. Jer već smo videli da, kao što zamenik Haskins ne može da uhapsi Čigura, tako ni Mos ne može da ga ubije, niti Bel da ga pobedi.

\section{Literatura:}

Abot, P. (2009). Uvod u teoriju proze. Prevela Milena Vladić. Beograd: Službeni glasnik

Bal, M. (2000). Naratologija. Prevela Rastislava Mirković. Beograd: Narodna knjiga

Cant, John. 2008. "No Country for Old Men." In Cormac McCarthy and the Myth of American Exceptionalism, 238-251. New York: Routledge

Devlin, W. J. (2010). No Country for Old Men, The Decline of Ethics and the West(ern). In J. L. McMahon and B. Steve Csaki (ed), The Philosophy of the Western (pp. 221-239). Lexington: The University Press of Kentucky.

Hutcheon, L. (2006). Beginning to Theorize Adaptation. In L. Hutcheon, $A$ Theory of Adaptation (pp. 1-32). New York: Routledge.

King, L. C., Wallach R., and Welsh J. eds. (2009). No Country for Old Men, From Novel to Film. Lanham, Toronto, Plymouth, UK: Scarecrow Press 
Makarti, K. (2008). Nema zemlje za starce. Preveli: Milan i Vuk Šećerović. Beograd: Laguna.

Vanderheide, J. (2009). No Allegory fo Casual Readers. In L. C. King, R. Wallach, and J. Welsh (ed), No Country for Old Men, From Novel to Film (pp. 32-45). Lanham, Toronto, Plymouth, UK: Scarecrow Press

Miloš S. Arsić

\section{Summary}

\section{A COMPARISON OF CHARACTERS IN CORMAC MCCARTY'S "NO COUNTRY FOR OLD MEN" AND THE FILM ADAPTATION BY BROTHERS COEN}

Although it is not the only common trait shared by the novel No Country for Old Men and its adaptation, the characterization in question nevertheless remains of the predominant motifs in the works of these authors, who utilize a specific genre as a basis for an authentic style. Analyses of a western-like setting is in the foreground of this work, together with the roles that the three main characters, Llewelyn Moss, sheriff Bell and Anton Chigurh play in it, their significance in the novel and the manner in which it was transferred to film. Deconstruction of western as a basis, comparison of methods in which the protagonist are portrayed, along with comparisons between the characters themselves will serve as key characterization devices. The objective is to gain a comprehensive insight into the characterization, based both on differences and similarities between the novel and the adaptation, because authenticity of style is evident in those differences just as much. Western itself merely suggests that there is no universal way to decipher all the layers of meaning. It gets deconstructed because of its failure to display all the complexities of life. The conflict between two opposing principles shown in the novel and the movie, with Moss caught in between, will never cease.

Key words: characterization, western, McCarthy, Coen, adaptation 